\title{
Chronology and evolution of the northern Iceland Plateau
}

\author{
J. CAMPSIE*, M. H. RASMUSSEN, L. C. KOVACS, F. DITTMER, J. C. BAILEY, N. O. HANSEN, J. LAURSEN \\ AND L. JOHNSON
}

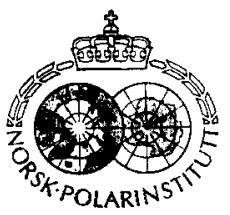

Campsie, J., Rasmussen, M. H., Kovacs, L. C., Dittmer, F., Bailey, J. C., Hansen, N. O., Laursen, J. \& Johnson, L. 1990: Chronology and evolution of the northern Iceland Plateau. Polar Research 8, 237243.

New aeromagnetic data, K-Ar age determinations of dredged marine igneous rocks, as well as other geophysical evidence have shed light on the chronology, nature and evolution of the northern Iceland Plateau. Correspondence between seismic refraction profiles taken on the Jan Mayen Ridge and westward through Jan Mayen Island, suppressed aeromagnetic anomalies, earthquake surface wave studies, and ages of dredged igneous rocks suggest these strata may form an extended region of thickened crust, possibly of Caledonian age, extending westward toward the Kolbeinsey Ridge and northwest to the south wall of the Jan Mayen Fracture Zone.

M. H. Rasmussen, F. Dittmer and J. Laursen, Ocean Study Group, Borgergade 34 2th, DK-1300 Copenhagen K, Denmark; J. C. Bailey, Ocean Study Group, Borgergade 342 th, DK-1300 Copenhagen K, Denmark, or Institute of Petrology, Ostervold Gade 10,DK-1350 Copenhagen, Denmark; N. O. Hansen, Institute of Petrology, Østervold Gade 10, DK-1350 Copenhagen, Denmark; L. C. Kovacs, Naval Research Laboratory, Washington D.C. 20375, U.S.A.; L. Johnson, Office of Naval Research, Arlington, VA 222175000, U.S.A.; February 1990 (revised August 1990).

In this paper new geophysical and chronological data are presented for the northern Iceland Plateau (Fig. 1). This is a region of relatively shallow seafloor, extending from the Jan Mayen Ridge in the east to Greenland in the west and from $70^{\circ}$ north to the Jan Mayen Fracture Zone. The southern boundary $\left(70^{\circ}\right)$ corresponds to the northern extent of the detailed magnetic and morphologic study by Vogt et al. (1980). The present plate boundary (Kolbeinsey Ridge) lies within the area of the study. The new magnetic data (Fig. 2) cover a gap in the coverage published by Kovacs et al. (1985) at the northernmost extent of Kolbeinsey Ridge. The age dating of dredged rocks from the region as well as their petrologic features yield insights into the chronology and evolution of this region.

The Iceland Plateau is generally a smooth flat plateau with a NNE-SSW welt raised by the Kolbeinsey Ridge. Its northern and eastern edges are dominated by flat topped seamounts, Jan Mayen Island and Jan Mayen Ridge (Fig. 1) (Johnson et al. 1972).

\footnotetext{
* We regret to say that John Campsie passed away on 20 October, before the publication of this article.
}

The Jan Mayen Fracture Zone, a transform fault, strikes WNW and morphologically is a prominent escarpment separating the Iceland Plateau from the Greenland Basin (Fig. 1). A seismic refraction line along the northern border (Fig. 3) (Sørnes \& Navrestad 1976) indicated less than $1 \mathrm{~km}$ of $2.5 \mathrm{~km} / \mathrm{s}$ sediment overlying $2-4 \mathrm{~km}$ of a $3.14 \mathrm{~km} / \mathrm{s}$ layer, which in turn overlies a $6.3 \mathrm{~km} / \mathrm{s}$ layer. The nature of the third layer is unknown, and may represent an extension of the Jan Mayen Ridge continental crust (Vogt 1986; Udintsev 1984; Myhre et al. 1984; Evans \& Sacks 1979; Fine et al. 1975; Johansen et al. 1988).

Presently, most investigators and ourselves are in favor of the hypothesis that the Jan Mayen Ridge is continental and split off from the Greenland margin when spreading commenced on Kolbeinsey Ridge about anomaly 6C time (24 Ma) (Vogt et al. 1980; Larsen 1984).

\section{Geophysics}

The US Navy has flown a series of aeromagnetic surveys in the Norwegian-Greenland Sea region (Vogt et al. 1980; Kovacs et al. 1985). In this paper we are reporting on a small area flown in 


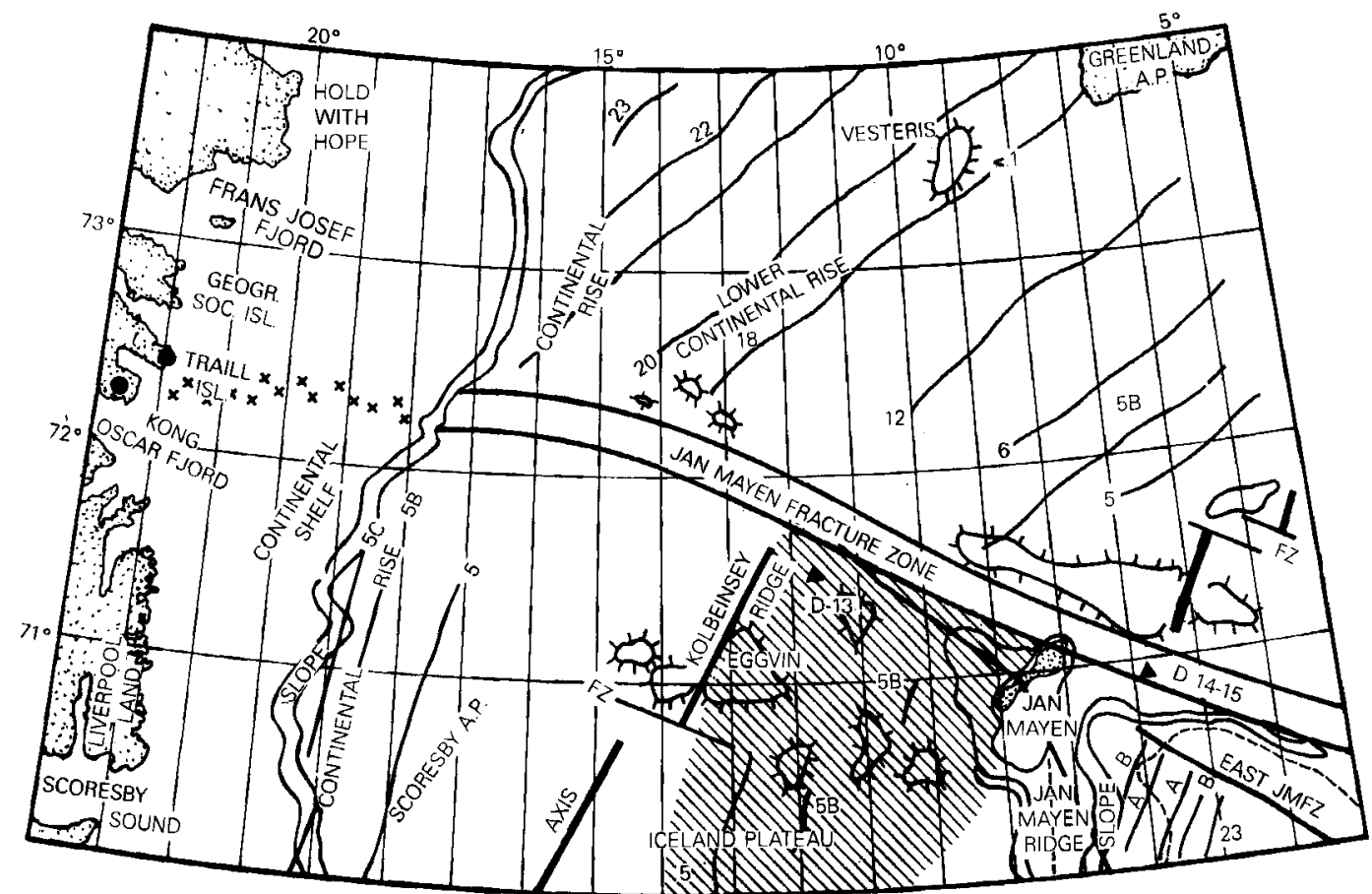

Fig. I. Physiographic chart of northern portion of the Iceland Plateau and environs. Xs are volcanic rocks on the shelf reported by Larsen (1984). Magnetic anomalies are from Skogseid \& Eldholm (1987), Larsen (1984), Kovacs et al. (1985), and this study. Dredge haul sites are indicated by a triangle. Vesteris Bank is shown as less than 100,000 years (Honjo pers. comm. 1987). Index for seismic refraction line (Fig. 3) is shown by heavy line and by a dashed line for Johansen et al. (1988). A hachured pattern indicates the area studied by Evans \& Sachs (1979).

1983 to fill a gap of the coverage of Kovacs et al. (1985). These data are integrated into the larger data set to give complete coverage of the entire region in Fig. 1. Also data from Larsen (1984) on the Greenland margin and from Skogseid \& Eldholm (1986) are included in Fig. 1. As delineated by Vogt et al. (1980), spreading began at Kolbeinsey Ridge about anomaly 6C time (24 Ma). As is evident from Fig. 1, ocean crust underlies much of the Greenland margin, suggesting extensive prograding during the PlioPleistocene.

Based on seismic refraction data (Fig. 1), Johansen et al. (1988) report for the northern Jan Mayen Ridge $1.5 \mathrm{~km}$ of post early Eocene sediment overlying $1 \mathrm{~km}$ of volcanic extrusive and interbedded sediment. Beneath this are about $3 \mathrm{~km}$ of pre-opening sediments thought to be Mesozoic. They further suggest that the underlying crust may be at least $13.5 \mathrm{~km}$ thick compatible with a continental crust. Myhre et al. (1984) also suggest the presence of Mesozoic rocks on the northern Jan Mayen Ridge and that the basement is of continental nature. Evans \& Sacks (1979) studied surface wave trains generated by earthquakes on the Jan Mayen Fracture Zone received in Akureyri, Iceland. The surface waves propagated along wavepaths, which are undisputedly oceanic through most of their lengths. These data may suggest a thickened crust of about $20 \mathrm{~km}$ as contrasted to normal ocean crust of $6-8 \mathrm{~km}$. Thus, the waves may have travelled along continental paths on the northern Iceland Plateau. The Jan Mayen Ridge is also the site of 3 drill holes (Talwani et al. 1976). Middle Miocene to Oligocene (?) sandy mud is present from 30-120 m depth. At $120 \mathrm{~m}$ depth an unconformity is observed beneath which a massive terrigenous Eocene sandy mudstone bottomed out all the drill holes. It would appear that our dredge site \#14 may also have sampled this layer (Fig. 1). 


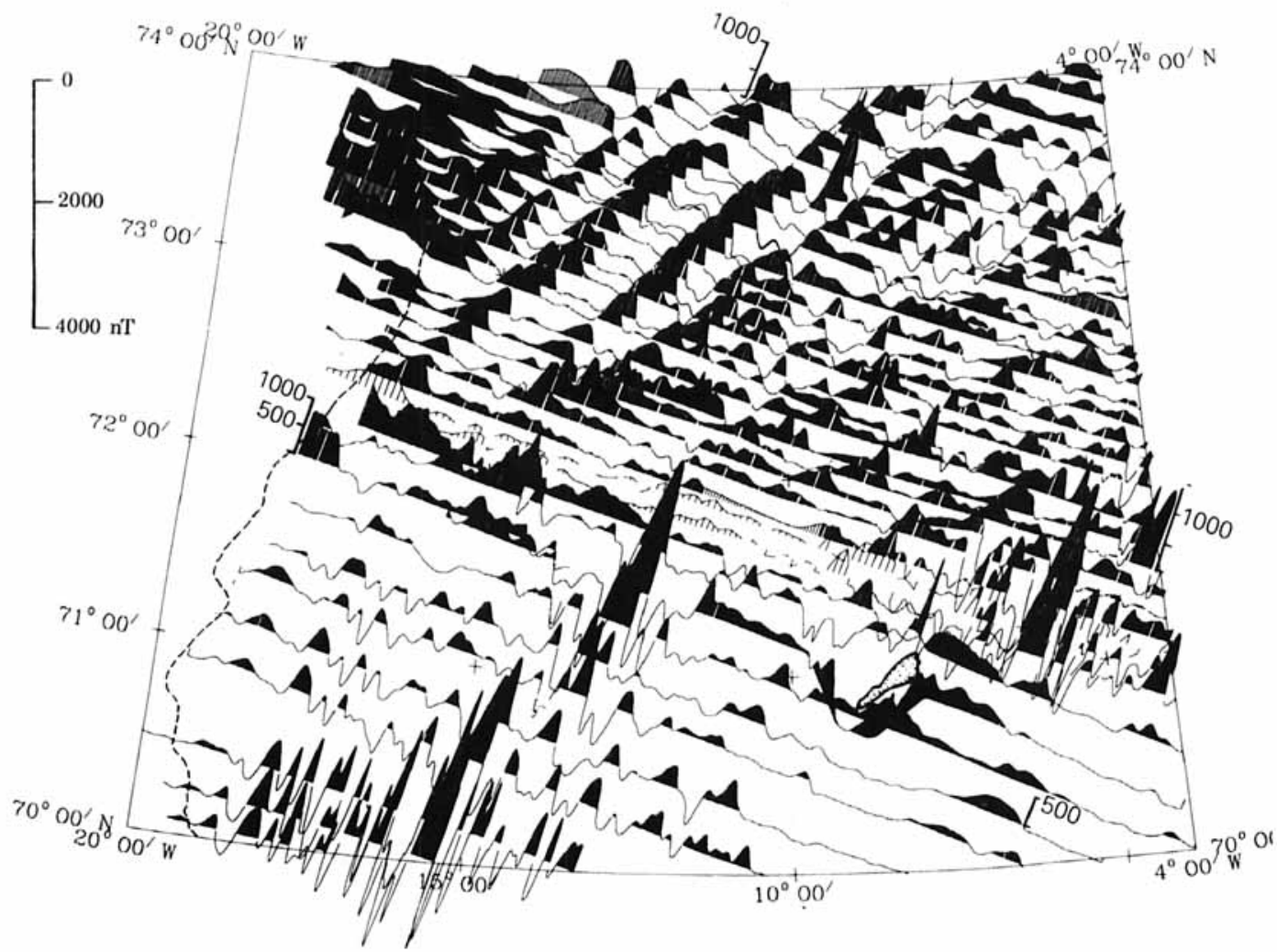

Fig. 2. Magnetic anomaly pattern from this study merged with the Mohns Ridge survey (Kovacs et al. 1985). Data plotted on polar stereographic projection.

\section{Age and composition of rock samples}

During the autumn of 1973, USNS 'Lynch' surveyed the western Jan Mayen Fracture Zone. Rocks were dredged from the fracture zone and from adjacent areas to the north and south (Campsie 1976) (Fig. 1). The Kolbeinsey Ridge axis yielded typical ocean ridge tholeiites except on Eggvin Bank at $71^{\circ} \mathrm{N}$ where the basalts contain higher concentrations of $\mathrm{K}, \mathrm{Ti}$, and $\mathrm{Sr}$ (Dittmer et al. 1975). On the shallow banks in the northern part of the Iceland Plateau and on the topographic highs north of the fracture zone the recovered igneous rocks are alkaline (Campsie 1976; Pedersen et al. 1976). On petrologic and isotopic grounds they define an extensive Jan Mayen volcanic province. Additional samples have been recovered from DSDP site 345 (Vogt 1986) and by a University of Rhode Island cruise (Neumann \& Schilling 1984). The DSDP site 345 recovered alkali enriched basalt southeast of the eastern end of the Jan Mayen Fracture Zone.

Dredge \#13 was recovered from a 3,000 meter depression at the northern extension of Kolbeinsey Ridge at $71^{\circ} 33^{\prime} \mathrm{N}, 11^{\circ} 36^{\prime} \mathrm{W}$ - depth $2,500 \mathrm{~m}$ (Fig. 1). A seismic reflection line across the depression (Johnson \& Campsie 1976) shows a lack of sediment accumulation and an irregular rough bottom indicative of youth and faulting. From the rugged south wall of this depression and about $45 \mathrm{~km}$ (magnetic anomaly age $4.5 \mathrm{Ma}$ ) east of the termination of Kolbeinsey Ridge axis dredging recovered $60 \mathrm{~kg}$ of rock material. The recovered fragments were angular; most surfaces had a thin film of ferric oxide and manganese crusts were absent. Among fragments larger than $5 \mathrm{~cm}$ about $50 \%$ were coarse grained clinopyroxenites and $40 \%$ were doleritic. This consistency of rock types strongly suggests the dredge contained in situ material.

Ultramafic rocks have often been recovered 
Table 1. Major and trace element analysis from dredges around the Jan Mayen Fracture Zone.

\begin{tabular}{|c|c|c|c|c|c|c|c|c|c|c|c|}
\hline $\begin{array}{l}\text { Sample no. } \\
\text { Dredge no. }\end{array}$ & $\begin{array}{l}26152 \\
13\end{array}$ & $\begin{array}{l}26006 \\
13\end{array}$ & Tayl. 1 & $\begin{array}{l}26166 \mathrm{~A} \\
13\end{array}$ & $\begin{array}{l}26166 \mathrm{~B} \\
13\end{array}$ & $\begin{array}{l}26162 \\
13\end{array}$ & $\begin{array}{l}26004 \\
13\end{array}$ & $\begin{array}{l}26161 \\
13\end{array}$ & $\begin{array}{l}345 \\
\text { DSDP } 33.2\end{array}$ & $\begin{array}{l}26238 \\
15\end{array}$ & $\begin{array}{l}26267 \\
14\end{array}$ \\
\hline $\mathrm{SiO}_{2}$ & 45.80 & 49.80 & 47.6 & 64.5 & 48.5 & 50.4 & 50.7 & 49.90 & 51.21 & 46.18 & 51.38 \\
\hline $\mathrm{TiO}_{2}$ & 0.56 & 0.65 & 0.5 & 1.09 & 2.90 & 1.95 & 2.70 & 1.95 & 1.83 & 3.16 & 2.88 \\
\hline $\mathrm{Al}_{2} \mathrm{O}_{3}$ & 2.34 & 4.60 & 4.8 & 15.4 & 14.70 & 14.1 & 13.1 & 14.40 & 17.80 & 16.07 & 15.88 \\
\hline $\mathrm{Fe}_{2} \mathrm{O}_{3}$ & 4.97 & 2.44 & 2.9 & 2.03 & 6.61 & 7.22 & 5.35 & 4,0 & 1.01 & 4.48 & 6.07 \\
\hline $\mathrm{FeO}$ & 3.87 & 3.71 & 5.6 & 3.39 & 6.20 & 3.41 & 8.48 & 7.65 & 8.17 & 6.92 & 4.26 \\
\hline $\mathrm{MnO}$ & 0.15 & 0.09 & 0.0 & 0.09 & 0.27 & 0.21 & 0.21 & 0.22 & 0.22 & 0.18 & 0.28 \\
\hline $\mathrm{MgO}$ & 24.00 & 17.9 & 18.5 & 1.83 & 5.81 & 7.55 & 4.96 & 8.88 & 9.01 & 6.43 & 4.26 \\
\hline $\mathrm{CaO}$ & 12.50 & 18.00 & 18.7 & 3.79 & 8.02 & 8.78 & 7.54 & 9.75 & 7.47 & 10.26 & 6.50 \\
\hline $\mathrm{Na}_{2} \mathrm{O}$ & 0.22 & 0.26 & 0.5 & 4.04 & 3.29 & 3.07 & 2.72 & 2.80 & 2.56 & 2.86 & 4.42 \\
\hline $\mathrm{K}_{2} \mathrm{O}$ & 0.06 & 0.27 & 0.0 & 2.34 & 1.96 & 1.48 & 1.99 & 0.20 & 0.73 & 1.12 & 1.05 \\
\hline $\mathrm{P}_{2} \mathrm{O}_{5}$ & 0.01 & 0.50 & & 0.23 & 0.67 & 0.41 & 0.50 & 0.21 & & 0.45 & 0.57 \\
\hline $\mathrm{H}_{2} \mathrm{O}$ & 5.38 & 1.66 & 0.7 & 0.99 & 1.08 & 1.21 & 1.35 & 3.80 & & 0.97 & 0.97 \\
\hline $\mathrm{H}_{2} \mathrm{O}^{+}$ & 0.63 & & & 0.63 & 0.35 & 0.80 & 0.89 & & & $0.18^{+}$ & $1.33^{+}$ \\
\hline Sum & 99.89 & 99.90 & & 100.35 & 100.36 & 99.79 & 100.49 & 99.0 & 100.01 & 99.51 & 99.85 \\
\hline
\end{tabular}

Tayl. 1: Olivine pyroxerite from Duke Isl., p. 102 (Taylor 1967).

+ LOI

345 DSDP: Init. Rep. 38, p. 732 (Ridlcy et al. 1976).

26238, 26267: Anal. Thesis, pp. 57, 54 (Fine 1980).

from mid-ocean ridges and fracture zones in the Atlantic and Indian Oceans (e.g. Engel \& Fisher 1969). Harzburgite, lherzolite, and dunite appear to be the most important rock types, whereas clinopyroxenites are rare. Hekinian (1970) briefly described fragments of clinopyroxenite and gabbro from the $\mathrm{Ob}$ Trench. On oceanic islands, e.g. Hawaii and the Canary Islands, clinopyroxenites are found as xenoliths (White 1966; Kuno 1969). They are usually regarded as crystal cumulates formed in the lower crust or the uppermost mantle. However, unlike other ultramafic nodules and xenocrysts (e.g. on Jan Mayen Island) the dredge \#13 clinopyroxenites have suffered considerable serpentinization.

Macroscopically the ultramafics exhibit banding or layering and two distinct generations of fracture development. The rocks consist of $60-90 \%$ relatively fresh clinopyroxene (diopside), generally having the composition $\mathrm{Ca} 46 \mathrm{Mg} 47, \mathrm{Fe} 7$ (Campsie 1976). The remainder of the rocks are largely composed of schlieren or patches of serpentine masses.

Our preliminary fabric analysis suggests that the ultramafics of dredge $\# 13$ have not undergone the intense shearing which appears to characterize many ultramafic rocks from the ocean floor. Clinopyroxenites having a similar composition to those reported here are commonly associated with orogenic belts (Taylor 1967)
(Table 1). In Table 2 the ages of these ultramafic rocks are presented. These rocks yield ages of $529 \pm$ ' 36 and $304 \pm$ ' 9 ma. These ages may be considered as falling within Caledonian time. The micro dolerites of dredge \#13 have undergone varying degrees of recrystallization or metamorphism in the greenschist-amphibolite facies, and have been brecciated and penetrated by numerous siliceous alkali enriched intrusions. In one case a doleritic fragment is seen embedded within a leucratic vein, and a poikiloblastic Kfeldspar has been observed in the dolerite. As can be seen in Table 1, samples most closely associated with the leucocratic intrusions, e.g. sample 26166B (doleritic fragment included in syenitic vein $26166 \mathrm{~A}$ ) and 26004 , have the highest mobile element concentrations.

The ages of the dolerites (Table 2) range from 6.51 to $19.3 \pm$ ' $1.6 \mathrm{Ma}$. Sample 26164 , the largest micro doleritic fragment, yielded ages of 7.1 and 19.3 Ma for separate samples of this block, thus indicating inhomogeneities. Sample 26004A (Table 2) is a K-feldspar enriched vein in dolerite sample 26004 and yields the youngest of all ages, $6.5 \mathrm{Ma}$, while 26004 has an age of 7.9 Ma. We suggest these ages do not reflect the true age of the seafloor as determined by distance from the spreading axis, but rather an alteration event to rocks of early Miocene/late Oligocene age. The metamorphic recrystallization processes probably 
Table 2. Ages of rocks from dredges 13,14 , and 15 .

\begin{tabular}{|c|c|c|c|c|c|c|}
\hline Sample no. & Location & Rock type & an $\mathrm{K}$ & $40 \mathrm{Ar}, \mathrm{ppm}$ & ${ }^{40} \mathrm{AR} / \mathrm{K}$ & Age \\
\hline 26400 & D-13 & Dolerite & 1.395 & .000762 & .00458 & $7.9 \pm 0.6$ \\
\hline 26160 & D-13 & Dolerite & 1.692 & .000799 & .000396 & $6.8 \pm 0.5$ \\
\hline 26162 & D-13 & Dolerite & 1.220 & .000606 & .000416 & $7.2 \pm 0.6$ \\
\hline 26163 & D-13 & Dolerite & 1.900 & .000875 & .000386 & $6.6 \pm 0.5$ \\
\hline 26164 & D-13 & Dolerite & 1.586 & .000785 & .000415 & $7.1 \pm 0.5$ \\
\hline $26166 \mathrm{~A}$ & D-13 & Syenitic vein & 2.174 & .0001134 & .000437 & $7.5 \pm 0.5$ \\
\hline 26152 & D-13 & Clinopyroxenite & 0.024 & .001018 & .02572 & $529 \pm 36$ \\
\hline 26238 & D-15 & Alkaline basalt & 1.018 & .0002141 & .001763 & $30.1 \pm 1.6$ \\
\hline 26267 & D-14 & Alkaline basalt & 0.999 & .001819 & .001527 & $26.1 \pm 1.4$ \\
\hline 26279 & D-14 & Tholéitic basalt & 0.330 & .000713 & .001811 & $\begin{array}{l}30.9 \pm 2.5 \\
\text { Geochron dates }\end{array}$ \\
\hline $26004 \mathrm{~A}$ & D-13 & $\mathrm{K}$-feldspar rich vein & & & & 6.51 \\
\hline 26164 & D-13 & Dolerite & & & & $19.3 \pm 1.6$ \\
\hline 26152 & D-13 & Clinopyroxenite & & & & $\begin{array}{l}304 \pm 9 \\
\text { Institut for } \\
\text { Petrologi dates }\end{array}$ \\
\hline
\end{tabular}

occurred as a result of the alkali rich intrusion at a time between 6.5 and $7.5 \mathrm{Ma}$ (samples 26004A and 26166A).

Sample 26161 (undated) is relatively unaltered, having a low $\mathrm{K} 2$ and mobile trace elements, and is similar in composition to basalts documented from East Greenland and the NorwegianGreenland Sea (Ridley et al. 1976; Melchior Larsen \& Watt 1985).

Dredges \#14 and \#15 were recovered about $70 \mathrm{~km}$ east of Jan Mayen Island from a scarp which marks the northern extent of the well documented continental Jan Mayen Ridge. Dredge \#14 $\left(70^{\circ} 54.7 \mathrm{~N}, \quad 06^{\circ} 34.7 \mathrm{~W}\right) \quad(1,800-2,200$ meters $)$ recovered $70 \mathrm{~kg}$ of dominantly spilitized basaltic breccias, whereas dredge \#15 $\left(70^{\circ} 53.9 \mathrm{~N}\right.$, $\left.06^{\circ} 35.7 \mathrm{~W}\right)(1,100-1,300$ meters $)$ consisted of basaltic lavas and subordinate tuffaceous material, and a sandy residue containing angular quartz grains. These sediments appear to have an age based on foraminifera of Miocene to Upper Eocene (Porthault 1975). Such lithologies and ages have been well documented further south in the DSDP holes (Talwani et al. 1976).

Three samples of recovered balsaltic rocks yield ages of $26.1 \pm ' 1.4$ to $30.9 \pm ' 2.5 \mathrm{mg}$ (Upper Oligocene) (Tables 1 and 2). Sample 26279 has $\mathrm{K}=.330 \%$ and $\mathrm{Rb}$ of $2.4 \mathrm{ppm}$. It thus has a tholeiitic composition and yields the oldest age of these two dredges. It is similar in composition to 26161 recovered from dredge $\# 13$ about $200 \mathrm{~km}$ to the west (Fig. 1, Table 1). These ages are compatible with the early rifting of the
Iceland Plateau. Similar lithologies, ages, and compositions have been reported for DSDP site 345. Gudlaugsson et al. (1988) have reported a major volcanic event postdating the block faulting of Jan Mayen Ridge, which is of probable earliest Miocene (about $20 \mathrm{Ma}$ ).

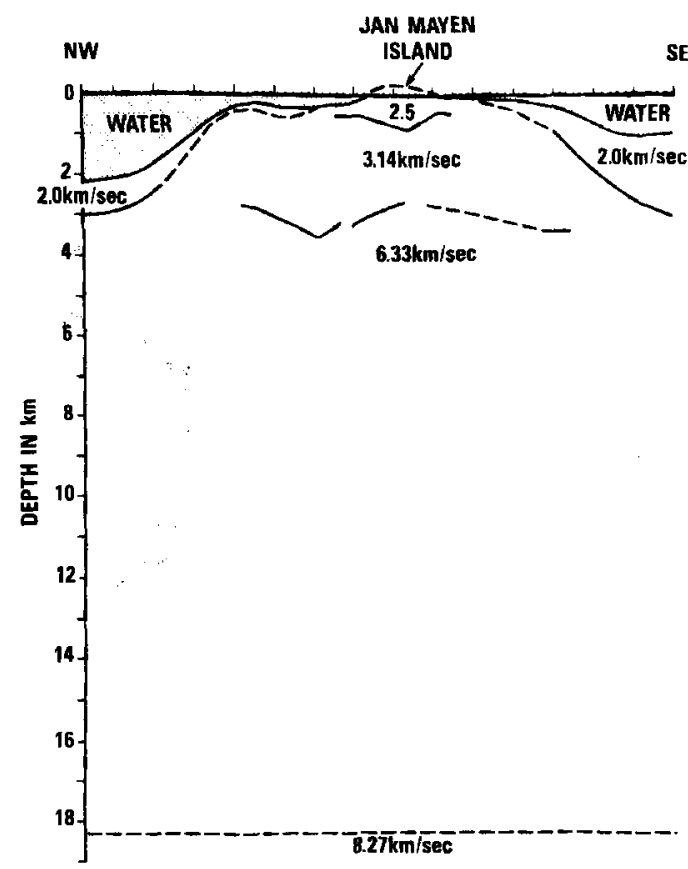

Fig. 3. Seismic refractions are modified from Sørnes \& Navrestad (1976), illustrating crustal velocities and thickness. Line indexed on Fig. 1 passing through Jan Mayen Island. 


\section{Discussion}

The increasing body of geophysical data, including seismic refraction and aeromagnetic data (this paper) when combined with rock ages presented here, suggest a large area of the northern Iceland Plateau may be underlain by basement of variable thickness and of possible Caledonian age. The irregular and difficult to correlate magnetic pattern of the eastern flank of Kolbeinsey Ridge north of $71^{\circ} \mathrm{N}$ within the area studied by Evans \& Sacks (1979) (Fig. 1) might fit this pattern. The irregularity may be due to the presence of continental crust consisting of thick sediments or caused by local volcanic outbursts from the nearby volcanic plateaus such as Eggvin Bank. These plateaus may also reflect anomalous crustal structure in this region. To the west of the ridge axis normal seafloor magnetic anomalies are present (Fig. 2).

As noted earlier, the ages for the doleritic rocks of dredge \#13 may not reflect their true age. We suggest the true age may be about $30 \mathrm{Ma}$, as this is similar to the ages of dredge \#14 and dredge $\# 15$ basalts. This may reflect initial rifting of the Iceland Plateau with subsequent rifting of the Jan Mayen Ridge (24 Ma).

The $6.3 \mathrm{~km} / \mathrm{s}$ layer in Fig. 3 would correspond to a basement of possible Caledonian age, the $3.14 \mathrm{~km} / \mathrm{s}$ to Layer $\mathrm{O}$, and the clinopyroxenities to the crystalline basement of Caledonian age (Myhre et al. 1984). Such clinopyroxenites are commonly associated with early stages of orogeny (Taylor 1967). Similar age samples (gneisses and schists) have been reported from the northern Iceland Plateau $\left(70^{\circ} \mathrm{N}\right)$ by Demenitskaya \& Dibner (1966) and Kotenev (1968). The latter, based on samples near the western end of the Iceland-Faeroe Ridge, suggests continental rocks may be present in this locale.

We suggest basement of Caledonian age may be present continuously under the Jan Mayen Ridge, and may extend west beneath Jan Mayen Island toward the site of dredge \#13 (shaded area Fig. 1). Kotenev (1968) believes it may extend south of the Jan Mayen Ridge to the vicinity of Iceland. Reconstructions to the time of opening place Jan Mayen Ridge within the Caledonian province (Bott 1985). The Caledonian province west of Jan Mayen Island, however, cannot be extensive due to plate tectonic space problems (Gudlaugsson pers. comm. 1989). Thus, it cannot be ruled out that the anomalously thick crust may in part be of Caledonian age, and that the alkaline volcanics of Jan Mayen might reflect partial fusion of such crust. This is seen in xenoclastic and xenocrystic rocks of Jan Mayen (Imsland 1984).

Acknowledgements. - We thank the officers and crew of the USNS 'Lynch' and of the Naval Research Laboratory Flight Support Detachment. Dating of samples was by Gcochron Laboratories, Cambridge, Massachusetts, and P. M. Holm, Geologisk Centralinstitut, Copenhagen. S. Fine generously provided data from his thesis. The manuscript benefitted greatly from the review of S. Gudlaugsson and A. Myhre, and two anonymous reviewers.

\section{References}

Bott, M. H. P. 1985: Plate tectonic evolution of the Icelandic transverse ridge and adjacent regions. Journ. Geophys. Res. 90, 9953-9960.

Campsie, J. 1976: Vulkanske bjergarter fra oceanbunden omkring Jan Mayen. Dansk. geol. Foren. Årsskrifi 1975, 3739.

Demenitskaya, R. M. \& Dibner, V. D. 1966: Morphological structure and the earth's crust of the arcs. Geol. Survey of Canada Paper 66-15, 62-79.

Dittmer, F., Fine, S., Rasmussen, M., Bailcy, J. C. \& Campsie. J. 1975: Dredged basalts from the Mid-Oceanic Ridge north of Iceland. Nature 254,298-301

Engel, C. G. \& Fisher, R. L. 1969: Lherzolite, anorthosite, gabbro and basalt dredged from the Mid-Indian Ocean Ridge. Science 11, 1136-1141.

Evans, J. R. \& Sacks, I. S. 1979: Deep structure of the Iceland Platcau. Journ. Geophys. Res. 84, 6859-6866.

Finc, S. 1980: Petrology and tectonic significance of dredged bolcanic rocks recovered east of Jan Mayen Island. NorwegianGreenland Sea. Thesis, University of Copenhagen. $146 \mathrm{pp}$.

Fine, S., Rasmussen, M., Campsic. J. \& Dittmer, F. 1975: The petrologic evolution of the Iccland Plateau. Trans. Am. Geophys. Un. 56, 45.

Gudlaugsson, S. T., Gunnarsson, K., Sand, M. \& Skogseid, J. 1988: Tectonic and volcanic events at the Jan Mayen Ridgc microcontinent. Pp. 85-93 in Morton, A. C. \& Parson, L. M. (eds.): Early Tertiary volcanism and the opening of the NE Atlantic. Geological Society Special Publication 39.

Hekinian, R. 1970: Gabbro and pyroxenite from a deep sea core in the Indian Ocean. Mar. Geol. 9, 287-294.

Imsland, P. 1984: Petrology, Mineralogy and Evolution of the Jan Mayen magma system. Nordic Volcanologic Institute, Reykjavik, Iceland. $332 \mathrm{pp}$.

Johansen, B., Eldholm, O., Talwani, M., Stoffa, P. \& Buhl, P. 1988: Expanding spread profile at the northern Jan Mayen Ridge. Polar Research 6, 95-104.

Johnson, G. L., Southall, J. R., Young, P. W. \& Vogt, P. R. 1972: Origin and structure of the Iceland Plateau and Kolbeinsey Ridgc. Journ. Geophys. Res. 77, 5688-5696.

Johnson, G. L. \& Campsic, J. 1976: Morphology and structure of the western Jan Mayen Fracture Zone. Norsk Polarinstitutt Ảrbok 1974, 69-81.

Kotenev, B. N. 1968: Marine geological studies in the vicinity of Iceland. Okeanologija 8, 1049-1052. 
Kovacs, L. C.. Bernero, C., Johnson. G. L.. Pilger, R. H., Jr., Srivastava. S. P.. Vink. G. E. \& Vogt, P. R. 1985: Residual Magnetic Anomaly Chart of the Arctic Ocean Region. Geological Society of America Map and Chart Series MC-53.

Kuno, H. 1969: Mafic and ultramafic nodules in basaltic rocks of Hawaii. Geol. Soc. Am. Mem. 115. 189-234.

Larsen. H. C. 1984: Geology of the North European Margin. Pp. 329-339 in Spencer. A. M. ct al. (eds.): Petroleum geology of the North European Margin. Graham and Trotman, London.

Mclchior Larsen. L. \& Watt. W. S. 1985: Episodic volcanism during break-up of the North-Atlantic. Evidence from the East Greenland Plateau basalts. Earth and Planet. Sci. Lett. $73,105-116$

Myhre, A. M.. Eldholm, O. \& Sundvor. E. 1984: The Jan Mayen Ridge: Present status. Polar Research 2, 47-59.

Neumann, E. R. \& Schilling. J. G. 1984: Petrology of basalts from the Mohns-Knipovich Ridge, the Norwegian-Greenland Sca. Contrib. Mineral. Petrol. 85, 209-223.

Pedersen. S., Larsen. O., Hald. N., Campsie, J. \& Bailey. J. C. 1976: Strontium isotope and lithophile clement values from the submarine Jan Maven province. Geol. Soc. Denmark Bull. 25, 15-20).

Porthault, B. 1975: Gcological study of dredge samples from Jan Mayen Ridge and East Greenland offshore. Soc. Nat. des Petroles d'Aquitaine. Note R/GEO 124/75. $12 \mathrm{pp}$.

Ridley, W. I., Perfit. M. R. \& Adams, M.-L. 1976: Petrology of basalts from Deep Sea Drilling Project Leg 38. Pp. 731740 in Talwani, M. et al.: Initial Reports of the Deep Sea Drilling Project 38. U.S. Government Printing Office. Washington.

Skogseid. J. \& Eldholm. O. 1986: Early Cenozoic Crust at the Norwegian Continental Margin and the conjugate Jan Mayen Ridge. Journ. Geophys. Res. 92, 11471-11491.

Sørncs. A. \& Navrestad, T. 1976: Scismic survey about Jan Mayen. Norsk Polarinst. Arbok 1975, 37-52.

Talwani, M., Udintsev, G. \& White, S. 1976: Introduction and exploratory notes, Leg 38 Deep Sea Drilling Project. Pp. 319 in Talwani. M. et al.: Initial Reports of the Deep Sea Drilling Project 38. U.S. Government Printing Office, Washington.

Taylor, H. P. 1967: The zoned ultramafic complexes of south eastern Alaska. Pp. 97-121 in Wyllie, P. J. (ed.): Ultramafic and related rocks. John Wiley, New York.

Udintsev, G. B. 1984: Norwegian-Greenland Basin rafting and oceanization in arctic geology. 27 International Geological Congress 4. Nantea. Moscow, 58-66.

Vogt. P. R., Johnson. G. L. \& Kristjansson, L. 1980: Morphology and magnetic anomalics north of Iceland. Journal. Geophys. 47. 67-80.

Vogt. P. R. 1986: Geophysical and geochemical signature and plate tectonics in the Nordic Seas. Springer-Verlag. New York, 413-662.

White, R. W. 1966: Ultramafic inclusions in basaltic rocks from Hawaii. Contr. Mineral. Petrol. 12, 245-314. 
